\title{
Migrant Children and Youth "On the Move": Between the Legacy of the Past and Challenges of the Future
}

\begin{abstract}
The paper presents thematic analyses relating to migration processes, situated between the Legacy of the Past and Challenges of the Future. The authors focus on a complex migration process referring to key factors that characterise it as well as dominant concepts in host societies: segregation and integration. The theoretical considerations undertaken in the text are primarily oriented towards presenting the diverse situation of Migrant Children and Youth "On the Move” as a category of the young generation affected by migration processes. The text is an attempt to reflect on the functioning of migrant backgrounds in the context of children's and adolescents' integration with the new place of residence. Particular attention was drawn to fragile areas generating distance, social exclusion and consequently hindering the process of integration.
\end{abstract}

\section{Keywords:}

migration, migrants, children and youth “on the move”, social exclusion

\section{INTRODUCTION}

"Green light for the tourists, red light for the vagabonds” (Bauman, 1998, p. 93), as Zygmunt Bauman said several years ago, drawing attention to the dichotomy of migration processes in the 20th century. Being on the move, migration, or mobility are inherent qualities of social groups brought on by a range of individual, social, cultural, economic, climatic and political factors. People are on the move

1 Faculty of Education, University of Warsaw, Warsaw, Poland. E-MAIL: u.markowska-ma@uw.edu.pl ORCID: 0000-0003-0667-4164

2 Faculty of Pedagogy and Psychology, University of Bialystok, Bialystok, Poland. E-MAIL: k.sawicki@uwb.edu.pl ORCID: 0000-0002-8192-9975 
in search of safety, in pursuit of a better tomorrow, escaping persecution, driven by climatic change and wandering in the hope of improving their status and the status of their close ones. The world of migration is a world of dualism, divisions being an intrinsic quality of human collectives which generate new differences between individuals, groups or communities. Migration is a multi-layered phenomenon, conditioned by various factors. It is estimated that "in 2010 there were about 214 million migrants in the world, about 3.1 per cent of the world's population" (Alonso, 2011, p. 4) and in 2015 "around 244 million international migrants in the world, which equates to 3.3 per cent of the global population" (McAuliffe \& Ruhs, 2017, p. 4). Displaced people worldwide were calculated in 2005 at c. 763 million (Bell \& Charles-Edwards, 2013). Every year, the number of migrants and the number of accompanied or unaccompanied migrating children is increasing.

Children and adolescents are a particular social group being a party to - a recipient of the effects of this process. Since the onset of the migration crisis, we have been able to observe that children have become an important part of large scale migration waves taking place in various parts of the world. According to data from Concept Note on the Global Conference on Children on the Move (2017), approximately 50 million children by 2017, tread the path of migration, being on the move due to difficult life situation in the place of birth and health/life-threatening factors (external and internal determinants) in their living environments. Millions of children from tens of countries affected by conflict, war, climatic change and economic crisis have been deeply affected by migration in the last decade of the 21st century. UNICEF data indicate that presently over 25 million children are internally displaced or move across international borders as a consequence of violence, armed conflict, deprivation, climatic change, transformation connected with globalisation processes and due to natural disasters (UNICEF, 2018). The organisation Save the Children reports that in 2016, about 30 million children were on the move both within one country and across borders (Save the Children, 2016). Children migrated with parents, guardians or unaccompanied by adults. Children and youth on the move are an important group of migrants.

The term 'children on the move' refers, among others, to "children moving for a variety of reasons, voluntarily or involuntarily, within or between countries, with or without their parents or other primary caregivers" (International Organization for Migration, 2013, p. 7). Children on the move are particularly exposed to violence, neglect, risk of inadequate care and support on the part of adults, economic exploitation (child labour) or sexual exploitation as well as human and organ trafficking. Children on the move, also referred to as migrant children, constitute a group that is 
most exposed to human trafficking and abuse during migration and upon arrival in destination country. This primarily refers to working children (Reale, 2013).

Issues that are important in the migration process are those associated with the causes and circumstances of migration, refugeeism, socio-political situation in one's country of origin and the cultural baggage referring to the cultural script in which young people were raised (Markowska-Manista, 2016, p. 130). The developmental period in which the framework of identity is constructed is a particular challenge in the area of education and adaptation. It is particularly important in the case of children on the move, who negotiate their identity between their own culture, cultures of the place and a global universe of symbols and values as well as threats brought by the conditions of the new place and space of life. According to Ulf Hannerz's theory, these young people function in cosmopolitan societies, understood as "an intellectual and aesthetic stance of openness towards divergent cultural experiences” (Hannerz, 1990, p. 239) in which the competence of finding one's place in new cultures as well as meanings, symbols and values particular to them is especially desirable.

There have been many moments in the history of Europe in which various incomers appeared on its territory (both in micro- and macroscale), migrating in search of freedom, better living conditions, employment, escaping persecution and natural disasters. Guaranteeing migrants not only proper living conditions but also participation in culture and the process of education are special challenges. Effective integration of minorities with the society is a panacea for the exclusion and social marginalisation of individuals from migrant backgrounds.

The text reflects on the socio-cultural conditioning of the socialisation and upbringing of children and youth on the move in Europe, with a particular focus on challenges faced in research and education that fit into the concept of an intercultural opening of host and migrant societies.

\section{MIGRANTS IN EUROPE}

European societies form a particular multicultural conglomerate shaped by ethnic, national and religious groups. Discussing a "united Europe”, "European motherland", or the "European Union” is not only a task resulting from the implementation of a political and economic integration strategy. It is also an emphasis on the common cultural heritage of societies living on the Old Continent. Various events from the recent decade seem to complicate the ideas of migration policy. These events are associated with the situation called "migration crisis" in the me- 
dia and academic discourse (Markowska-Manista \& Pasamonik, 2017), as well as global transformations in the area of children's and adolescents' migration and refugeeism. Migration crisis is increasingly accompanied by an attitude of hostility towards refugees on the part of Europeans as well as an ill-considered and inconsistent policy of the European Union (see: Markowska-Manista \& Pasamonik, 2017, p. 7). The dynamic increase of the number of migrants, the majority of whom are refugees from countries affected by war, conflict, climatic or political crisis, is connected with a new quality of research and practices referring to the situation of children and adolescents.

Acquiring the language of the host country, finding employment and achieving financial independence, social activity, involvement in political life as well as absence of conflict with the law are indicators of integration (Hannerz, 1990, p. 239). In particular, they are reflected in the structural dimension (access to important social positions), the dimension of culture and identity (acquisition of the language of the host country as well as cultural norms, values and a sense of belonging), social dimension (affiliation to formal and informal social groups, building long-lasting relations with members of the host society), economic dimension (reflected in the scale of differences in income between migrants and autochthons) as well as social dimension (referring to, e.g. the scale of the problem of 'ghettoization') (Łotocki, 2009, p. 7).

According to the literature on the subject, three stages of refugees' migration experience can be distinguished: pre-migration stage, migration stage, and post-migration stage in the new host country (Wessels, 2014). Pre-migration stage refers to a life in the country of origin before departure/escape to the new country. It can be associated with both functioning in the conditions of "fragile" peace and the beginning of instability - before an armed conflict and existence in difficult wartime conditions connected with constant exposure to physical, psychological and emotional violence. The second stage is migration stage which involves escaping from one's country, in the case of refugees - a rushed escape without the possibility to say goodbye to the closest ones and take a greater number of important belongings. The third stage is post-migration phase, connected with starting a new life in the host country and problems arising from the new situation.

It must be added that contemporary migration is largely of mixed character. It does not occur linearly between the place of origin and the place of destination. Scholars and authors of reports commissioned by international organisations indicate that the majority of contemporary migrants are involved in mixed migration. It is principally characterised by shifting destinations, influenced by information received and conditions experienced on the route of migration (REACH, 2017, p. 8). 
The constant change accompanying migrants coincides with the dynamics of social change and the development of societies in host countries. As a consequence, it is necessary to consider both of these levels in the analyses of migration processes, particularly with reference to the situation of children and youth on the move.

\section{SEGREGATION VS. INTEGRATION}

The beginnings of para-scientific thinking about migrants in the category of a problem can be traced to the era of Enlightenment. Phillips and Bowling refer to a piece of work by Arthur de Gobineau from 1863 entitled "An Essay on the Inequality of Human Races”, in which the author ascribed a lower level of moral development and even a propensity to kill to the inhabitants of Africa (Marsh, 2006, p. 216). Several decades later, Cesare Lombroso saw interdependencies between ethnic origin and crime, as reflected in his concept of “stigmata degenerationis” (Rocque, 2017, pp. 28-29).

A particularly significant moment in the perception of migration took place between mid-20th century and the 1970s and was associated with the phenomenon of guest workers. Economic growth, the development of industry and infrastructure increased the demand for low-qualified labour force. It was assumed that the problem would be temporary and transitory, and the best solution would be to allow foreigners a short-term access to the labour market (Sawicki, 2016).

The crux of the problem is reflected in the term used for economic migrants of those times. The German Gastarbeiter (i.e., guest worker) is a person who (as the etymology of the word suggests) remains in the host country for a short period of time, as a "guest" (to improve one's economic situation), and eventually returns to his/her country of origin. In the case of the so-called "Old European Union”, there were two basic sources of cheap labour force: former colonies in the Mediterranean region (Morocco, Turkey, former Republic of Yugoslavia) as well as post-socialist countries. Social policy for migrants was limited to selectively perceived integration, exclusively in the socioeconomic dimension. In the dimension of culture and education, policy was oriented towards cultural distinctness of minority groups, which (as presumed by those responsible for migration policy) was to facilitate migrants' return to their countries of origin (Sawicki, 2017).

With time it became clear that the implementation of the idea of guest workers is difficult in practice since only a fraction of economic migrants was interested in returning to their homeland. Additionally, they started to bring their families to 
Europe, which demanded adjustments in migration policy that had to encompass not only individuals at productive age but also their spouses and underage children. A peculiar family model consolidated in migrant environment: with a high fertility rate, a housewife taking care of the household and children with problems with school attendance and conflict with the law. This necessitated a redefinition of the assumptions of social policy oriented towards migrant populations, providing social support and ensuring compulsory school attendance.

An additional problem lay in cultural differences which hindered diaspora members' integration with the environment (e.g., absence of the model of women's social and professional activity, ethical and moral principles acquired in the culture of origin). It must be stressed that migrant backgrounds strived to sustain the habitus of the group, which frequently inhibited social integration processes.

In such situations, the so-called neighbourhood effect (Ellen \& Turner, 1997, p. 848) takes on a special meaning; it assumes that the local level of a person's functioning, the place where people live and grow, plays a key role for the individual, for the group the individual co-creates as well as the environment, particularly in social and economic dimensions. This factor is of special importance in a situation when typical risk factors come into play: absence or shortage of well-educated individuals, high unemployment rate and a lack of proper parental care (Sampson, Morenoff, \& Gannon-Rowley, 2002). Scholars researching this subject draw attention to the fact that the accumulation of inhabitants with an unfavourable economic situation in a particular area contributes to a range of impediments in the functioning of the milieu's infrastructure. Long-term unemployment leads to an increased sense of helplessness and a lack of agency; it results in instability and an increase in deviant phenomena, and contributes to generating the so-called “underclass” (Wilson, 1987).

The concentration of minorities (mainly, ethnic minorities) in a particular district in combination with low socio-economic indicators of the environment generates the so-called "culture of poverty" (Lewis, 1961). As a result, social structures become disturbed: real property value decreases, middle class escapes to other districts, investment in the territory of the ghetto declines and maintenance of infrastructure (schools, leisure facilities, recreation areas) on a normal level is hindered. In literature on the subject, a rhetorical question is raised about whether migrants are poor and do not undertake employment because they live in a specific environment and suffer exclusion and social marginalisation, or on the contrary - they live in this environment because they are poor and unemployed. This situation becomes a source of problem behaviour and even conflict with the law, which has been indicated in a number of publications in the area of cultural criminology; it also impacts the relations with other minority groups as well as the dominant culture. 
It is worth stressing that the first wave of guest workers, referred to above, did not cause serious legal problems. Scholars indicate that they were associated with acts of deviance not so much due to symptoms, but rather the fact of residing in districts with a high crime rate (Bucerius, 2014; Junger-Tas et al., 2012). Only the second and third generation (children and grandchildren of guest workers) that grew up in unfavourable environmental conditions started to display increased criminal behaviour. The root of the problem lies in the fact that guest workers' children are part of a generation of perpetual "foreigners", who (as young people) faced unprepared systems of social support and education, exclusive rights and politicians; with time, they became too adult (now being too old) to benefit from recent social and educational programs for integration. In Germany this group is often called "the lost generation” (Die Beauftragte der Bundesregierung für Migration, 2007).

Infrastructural conditions also play a role. The specific character of districts inhabited by gastarbeiters can be described through reference to the Paris banlieues (Die Beauftragte der Bundesregierung für Migration. "Flüchtlinge und Integration”, 2007). They are urbanised regions inhabited by migrant and autochthonous populations. Their structure is primarily based on a resultant of class divisions rather than ethnic divisions (the latter of which are particular to American districts of poverty). The specifics of functioning of the second and third generation of migrants (i.e., individuals who were born or are parents to children born in banlieues) deserve particular attention in these areas. These are problematic adolescents, avoiding schooling, opposing activities aimed to improve their socioeconomic situation, exposed to exclusion and marginalisation, and as a result requiring prevention and resocialisation interventions.

As Ian Marsh et al. argue, social stratification and accommodating minorities on territories with neglected infrastructure are also sources of threat caused by terrorism that has been a growing problem in recent years. The authors stress that this type of criminal activity is particularly associated with the functioning of ethnic minorities (Marsh, 2006, p. 163).

Being a migrant increases the risk of being rejected and consequently disadapted. A negative attitude towards members of Muslim minorities in European countries can serve as an example. Being a stereotypical "Arab", "unassimilated Moroccan or Turk" is a barrier to integration and acculturation, sustains a sense of being alien (Bucerius, 2014). The negative overtone of public opinions and views is another factor that exacerbates the distance between migrants and the society (indigenous population). As James Lynch and Rita Simon say, "Kut Marokkanen” (“fucking Moroccan”) is a term used to refer to Moroccans in popular press in the Netherlands (Lynch \& Simon, 2002). In 2010, a Deutsche Bundesbank member Thilo Sarrazin 
(2010) triggered a national debate saying in his well-received book that Germans become biologically and culturally inferior because of Muslim immigrants. In this context, it is worth mentioning that according to the European Values Study, "antiMuslim prejudice was more significant than anti-immigrant prejudice among European majority populations already before September 11, 2001, and the ensuing terrorist attacks in Europe” (Fleischmann \& Phalet, 2018; Strabac \& Listhaug, 2008). Antimuslim attitudes are not indifferent to the functioning of Muslim communities in Europe, influencing identity formation among their members. It was reflected in the International Comparative Study of Ethnocultural Youth (ICSEY) project (Berry, Phinney, Sam, \& Vedder, 2006), according to which there is a negative correlation between young migrants' ethnic identity and the requirements of European societies (particularly in the case of representatives of Muslim minorities).

The patterns indicated above impact migrants' functioning that stands in opposition to the law. As Phillips and Bowling argue, while searching for the reasons why an increased crime rate in migrant backgrounds is discussed, two important elements can be noticed. Firstly, according to statistical data, there is a higher record of crime among migrant populations than indigenous populations in Europe, however (as the authors stress), there is absence of reliable data that would justify this state of affairs. Moreover, there is a problem with inadequate data and data leading to generalisations. Secondly, representatives of ethnic minorities (including migrants) do not commit more crimes than the rest of the population; the problem lies in bias present among law enforcement and judicial officers (Phillips \& Bowling, 2003). Thirdly, to cite Sandra Bucerius (2014), representatives of migrant environments experience various levels of acculturation and assimilation as well as exclusion in host societies, they are diversified with regard to ethnicity and age, consequently they are not a homogenous group, which makes their inclusion in the research framework difficult.

Nevertheless, migration also generates a range of negative, criminal side effects. Human trafficking is one of them. This contemporary version of slave trade is a pathological migration of people oriented towards cheap (or free) labour force. According to the UN Office on Drugs and Crime, this phenomenon has a character of economically-conditioned organised crime in which "victims are moved from poor environments to more affluent ones, with the profits flowing in the opposite direction [...]. It is believed to be growing fastest in Central and Eastern Europe and the former Soviet Union [although Nepal, Bangladesh, Thailand and the Philippines are also cited]. [...] Europol estimates that the industry is now worth several billion dollars a year" (UNODC, 2016). This situation is reflected in legislation, which draws particular attention to women and children. Appropriate regulations can be found not 
only in the United Nations Convention on the Rights of the Child. Also the United Nations Convention Against Transnational Organized Crime explains that 'trafficking in persons' means 'the recruitment, transportation, transfer, harbouring or receipt of persons, by means of the threat or use of force or other forms of coercion, of abduction, of fraud, of deception, of the abuse of power or of a position of vulnerability or of the giving or receiving of payments or benefits to achieve the consent of a person having control over another person, for the purpose of exploitation. Exploitation shall include, at a minimum, the exploitation of the prostitution of others or other forms of sexual exploitation, forced labour or services, slavery or practices similar to slavery, servitude or the removal of organs” (UN, 2000, p. 2). It serves as another example of a situation in which migrants are inscribed into a criminological context not as criminals, but victims.

\section{TOWARDS THE MIGRANT POLICY}

Within the majority of social policies, migrants are perceived as a "social problem", a "placeholder, marking memories of empire, or fears of globalization, or a sense of impending catastrophe" (Anderson, 2017, p. 1535) and a challenge for the social welfare and education in the host country. The inadequate or intrusive interventions/strategies lead to the escalation of further problems: poverty, lack of social participation, alienation, ghettoization, or criminalization (Ajmera \& Fields, 2016; Books, 2010; Clarke, 2011). Consequently, they become a secondary problem for the citizens of the societies in the Global North. As Zygmunt Bauman noted: "What we call 'refugee crisis' is but one of multiple manifestations of the state of 'interregnum' - one in which the habitual ways of acting have stopped working properly and bringing familiar results, but the new ways - more adapted to the changed conditions - are still at best stuck at the drawing-board stage” (Bauman, 2018, p. 2). Taking these processes into consideration, children and youth studies assume a particular importance as they not only point to the significance of analysing the processes, transformations and diagnoses, but also to the preparation of the host environment as well as the migrant environment for the formation of a unified collectivity (Blackwell, 2005).

All these challenges faced by children, adolescents and adults in a culturally and socially diverse world are a response to international migration and global transformations. They are associated with the impact of the environment, children's rights policies and trends in the support and development of the youngest generation of the citizens of our world (Furlong, 2009; James, Jenks, \& Prout, 1998; 
Lerner et al., 2011). The process of identity formation among the young generation/children and adolescents appears as a particularly important issue (Castells, 2010; Giddens, 1991). This process is influenced by environmental factors, among which family and the environments connected with it play the key role.

To illustrate this point, it is known that immigrant youth from the first and second generation have a strong sense of duty towards the family, which is associated with mutual help and taking family needs into consideration while making personal decisions. Even during adolescence loyalty towards parents can dominate over loyalty towards peers, meaning that being a dutiful son or daughter is more important than gaining recognition at school (Fuligni, Tseng, \& Lam, 1999).

These additional environments and factors are the effect of the process of socialisation, informal relations with peers and adults in the place of residence, the impact of schools, refugee centres and other institutions. The rules and norms observed as well as the values preferred in these institutions form young generations into a model specific to particular cultures. This naturally static process is significantly disrupted in the situation of radical changes - in the process of migration, moving to a new place of residence (Berry et al., 2006), refugeeism, or returning from economic migration. These factors prevent the process of identity formation from taking place in a customary form: due to the distinct environment as well as the rules, patterns and norms observed in the new environment (the host country) (Narchal, 2007).

The difficulties particularly involve cultural shock, problems with the new language, adaptation difficulties and a sense of uncertainty. One of the problems lies in children: their parents/guardians negotiating their way in the new place of residence and the new school environment conditioned by a cultural closing or opening of the host society and its particular environments, including educational environment. Another important aspect relating to migrant children and youth (either accompanied or unaccompanied by adults) is connected with shaping one's social identity and a sense (or lack thereof) of being part of the host society. As Johanna Wyn and Rob White pointed, "It is our view that social identity is constructed in the context of a series of lived experiences pertaining, in the first instance, to locality, family and community resources. Where one lives and grows up (that is, the physical terrain and social amenities available) has a major influence on how one literally sees the world, as well as how we directly experience things around us. Climbing trees or negotiating car traffic, tramping through wilderness or queuing at the zoo, coping with searing heat or soaking in waves of monsoonal rain - all speak to quite different local conditions, climates and personal relationships to the natural and built-up environments. The physicality of environment is a large part of how we experience the world around us” (Wyn \& White, 1997, p. 81). 
Among particularly important aspects are attempts to understand the fate and situations of children in the places and spaces of their new functioning in the socalled fragile contexts, which frequently fail to guarantee the observation and protection of children's rights. Other issues, important in the context of research, are connected with intersectionality, i.e., an interdisciplinary research perspective originating from postcolonial and minority studies. We still know little about discrimination against children and youth in the processes of migration and refugeeism and their impact on the construction of childhood in places and spaces that Janusz Korczak would call as being "not for children".

With the abovementioned patterns in mind, it must be stressed that relying on resilience can be an important element of educational processes when working with children and adolescents from migrant backgrounds. As Michael Ungar argues, it should consider "characteristics of environments that are most facilitative of resilience reflect the individual, family, and community's capacity to navigate to resources, the availability and accessibility of resources, and the meaningfulness of the resources provided" (Ungar, 2013).

In this sense, the impact of cultural differences on resilience is of key importance for the education of the young generation on the move, and to what extent it is prepared to face challenges connected with functioning in the new environment. This relates not only to functioning in new environmental conditions, but also to the situation of threat experienced in the place of residence. Examples of activities in Israeli preschools described by Ungar illustrate such an approach. Teachers in these preschools created an unpredictable environment (which is a quality particular to territories affected by armed conflict). The interventions are based on making children aware of the fact that they have to look after themselves, but they are not provided with guidelines on how to do it, how to avoid threat and danger. As the authors of the approach (cited by Ungar) argued, rather than organise the physical and social environment of upbringing in which the unpredictability of events is minimalised, children were encouraged to take responsibility for themselves (Ungar, 2013, p. 265).

\section{CONCLUSIONS}

The text is an attempt to reflect on the functioning of migrant backgrounds in the context of children's and adolescents' integration with the new place of residence, school, friends and teachers. Particular attention was drawn to fragile areas generating distance and consequently hindering the process of integration. 
It is our opinion that further research on an individual level is necessary, where comparisons are not based only on the analysis of big data, extended statistics generating divisions into "immigrant" and "indigenous" backgrounds, but where groups of "immigrants" and "autochthons" are divided based on generations, social status, origin or migration history including all factors connected with the time, places and spaces of functioning "in migration". In-depth ethnographic research can shed much light on immigrants' daily reality and adaptation problems which they face in host countries. To ensure that research on children and adolescents in the context of migration is reliable, access to adequate data is necessary. Without it, it is difficult to recreate life and migration stories of modern vagabonds, attenuate harmful patterns and trends, and consequently employ adequate integration procedures. Absence of reliable data that should be available in government agencies also translates to an increased probability of generating biased publications and reports, which exacerbates unjustified stereotypes and social distance.

It is worth mentioning that in the majority of reports and publications, the victimising element in the functioning of individuals from migrant backgrounds is ignored. The model that dominates research is based on identifying risk factors that generate problem behaviours, often in an intergenerational context, acquired in the living environment. Being a victim of harmful stereotypes and even repression on the part of representatives of dominant culture leads to educational resistance, exclusion and marginalisation, as well as unwillingness to participate fully in the society.

Regardless of the research problems indicated above and the perception of representatives of migrant backgrounds, a question must be posed about educational tasks realised for children and adolescents. In culturally and semantically complex realities, the key question that should be asked is about the principles of creating relativism in thinking about rules, formation of capacity for adaptation and flexibility. These are central skills which every young person needs to have to negotiate his or her way in the contemporary, global world. In the case of children and adolescents from migrant backgrounds, it is a situation in which they can use familial, cultural and social resources of the group of origin, and at the same time act for educational success or professional advancement being above stigmatising experiences and stereotypes. In other words, it leads to full participation of migrant children and youth in European societies.

Finding the answer to the questions posed above seems particularly important today, since alleviating the refugee and migration crisis has become a global political priority. In her essay “Can We Solve the Migration Crisis?”, Jacqueline Bhabha (2019) points to the key factor necessary for the support of migrating and 
escaping adults, adolescents and children. The scholar argues that forced migration and refugeeism require compassion, generosity, acknowledgement of our interdependence on mobility as a key element of global cooperation as well as development of solutions which aim to defeat inequality and conflicts that drive migration processes.

\section{References}

Ajmera, M., \& Fields, G.A. (2016). Invisible Children: Reimagining International Development at the Grassroots. London: Palgrave Macmillan.

Alonso, J.A. (2011). International Migration and Development: A review in light of the crisis (No. CDP Background Paper No. 11 (E)). Unirted Nations.

Anderson, B. (2017). Towards a new politics of migration? Ethnic and Racial Studies, (40), 1527-1537. https://doi.org/10.1080/01419870.2017.1300297.

Bauman, Z. (1998). Globalization: The Human Consequences. London: Polity Press.

Bauman, Z. (2018). Between separation and integration: Strategies of cohabitation in the era of diasporization and Internet. Popular Communication, 16(1), 1-3.

Bell, M., \& Charles-Edwards, E. (2013). Cross-national comparisons of internal migration: An update on global patterns and trends. New York: United Nations Department of Economic and Social Affairs.

Berry, J. W., Phinney, J. S., Sam, D. L., \& Vedder, P. (2006). Immigrant Youth: Acculturation, Identity, and Adaptation. Applied Psychology, 55(3), 303-332. https://doi.org/10.1111/ j.1464-0597.2006.00256.x.

Bhabha, J. (2018). Can we solve the migration crisis? Cambridge: Polity Press.

Blackwell, D. (2005). Counselling and psychotherapy with refugees. London: Jessica Kingsley Publishers.

Books, S. (Ed.). (2010). Invisible Children in the Society and Its Schools. Routledge.

Bucerius, S. (2014). Unwanted. Muslim Immigrants, Dignity, and Drug Dealing. New York: Oxford University Press.

Castells, M. (2010). The Power of Identity. Malden: Wiley - Blackwell.

Clarke, R.M. (Ed.). (2011). Antisocial Behavior: Causes, Correlations and Treatments. New York: Nova Science Publishers, Inc.

Die Beauftragte der Bundesregierung für Migration. „Flüchtlinge und Integration. (2007). Bericht der Beauftragten der Bundesregierung für Migration, Flüchtlinge und Integration über die Lage der Ausländerinnen und Ausländer in Deutschland. Retrieved from Die Beauftragte der Bundesregierung für Migration. „Flüchtlinge und Integration website: https://www.bundesregierung.de/resource/blob/975292/733032/018e285b5e07f6746b48 76d85c371765/7-auslaenderbericht-download-ba-ib-data.pdf?download=1.

Ellen, I.G., \& Turner, M.A. (1997). Does neighborhood matter? Assessing recent evidence. Housing Policy Debate, 8(4), 833-866. https://doi.org/10.1080/10511482.1997.9521280.

Fleischmann, F., \& Phalet, K. (2018). Religion and National Identification in Europe: Comparing Muslim Youth in Belgium, England, Germany, the Netherlands, and Sweden. Journal of Cross-Cultural Psychology, 49(1), 44-61. https://doi.org/1.o0r.g1/107.171/0770/20202 0202212171774411988. 
Fuligni, A.J., Tseng, V., \& Lam, M. (1999). Attitudes toward Family Obligations among American Adolescents with Asian, Latin American, and European Backgrounds. Child Development, 70(4), 1030-1044. Retrieved from JSTOR.

Furlong, A. (Ed.). (2009). Handbook of Youth and Young Adulthood: New Perspectives and Agendas. London: Routledge.

Giddens, A. (1991). Modernity and Self-Identity: Self and Society in the Late Modern Age. Cambridge: Polity Press.

Global Conference on Children on the Move. (2017, 13.06). Retrieved from http://www.childrenonthemove.org/wp-content/uploads/2017/02/Concept-Note-Global-Conference-onChildren-on-the-Move.pdf

Hannerz, U. (1990). Cosmopolitans and Locals in World Culture. In M. Featherstone (Ed.), Global Culture: Nationalism, Globalization, and Modernity (pp. 237-252). London: Sage.

International Organization for Migration. (2013). Children on the move. Geneva: International Organization for Migration〉.

James, A., Kenks, C., \& Prout, A. (1998). Theorizing Childhood. Cambridge: Polity Press.

Junger-Tas, J., Haen Marshall, I., Enzmann, D., Killias, M., Steketee, M., \& Gruszczyńska, B. (2012). The Many Faces of Youth Crime. Contrasting Theoretical Perspectives on Juvenile Delinquency across Countries and Cultures. New York-Doordecht-Heidelberg-London: Springer.

Lerner, R.M., \& Steinberg, L. (2011). The History of the Study of Adolescence. In B.B. Brown \& M.J. Prinstein (Eds.), Encyclopedia of Adolescence (Vol. 1, pp. 169-176). London: Elsevier.

Lewis, O. (1961). The Children of Sanchez: Autobiography of a Mexican Family. New York: Random House.

Łotocki, Ł. (2009). Integracja i dyskryminacja - krajobraz 2009. Warszawa: Instytut Spraw Publicznych.

Lynch, J., \& Simon, R. (2002). A Comparative Assessment of Criminal Involvement along Immigrants and Natives across Seven Nations. In J.D. Freilich (Ed.), Migration, Culture Conflict, and Crime (pp. 273-290). Aldershot: Darmouth Publishing Company.

Markowska-Manista, U. (2016). Praca z uczniem z trudnościami adaptacyjnymi-specyfika różnic kulturowych i zmiany środowiska edukacyjnego. In E. Emilia ŚmiechowskaPetrovskij (Ed.), Dzieci z trudnościami adaptacyjnymi w młodszym wieku. Aspekty rozwojowe i edukacyjne w kontekście specyfiki różnic kulturowych (pp. 125-147). Warszawa: UKSW.

Markowska-Manista, U., \& Pasamonik, B. (2017). Wprowadzenie (O kryzysie migracyjnym z perspektywy pedagogiczno-psychologicznej). In U. Markowska-Manista \& B. Pasamonik (Eds.), Kryzys migracyjny: perspektywa pedagogiczno-psychologiczna: Vol. 2. (pp. 7-14). Warszawa: Wydawnictwo APS.

Marsh, I. (2006). Theories of crime. London and New York: Routledge.

McAuliffe, M., \& Ruhs, M. (2017). World Migration Report 2018. Geneva: International Organization for Migration.

Narchal, R. (2007). Migration: Destruction and reconstruction of the self. Sensoria: A Journal of Mind, Brain \& Culture, 3(1), 55-64. https://doi.org/10.7790/ejap.v3i1.80 
Phillips, C., \& Bowling, B. (2003). RACISM, ETHNICITY AND CRIMINOLOGY: Developing Minority Perspectives. The British Journal of Criminology, 43(2), 269-290. Retrieved from JSTOR.

REACH. (2017). Youth on the Move Investigating decision-making, migration trajectories and expectations of young people on the way to Italy. Retrieved from http://www.mixedmigration.org/wp-content/uploads/2018/05/040_youth-on-the-move.pdf.

Reale, D. (2013). Protecting and supporting children on the move: Translating principles into practice. Children on the Move, 20. Retrieved from: https://publications.iom.int/system/ files/pdf/children_on_the_move_15may.pdf.

Rocque, M. (2017). Desistance from Crime. New Advances in Theory and Research. New York: Palgrave Macmillan.

Sampson, R.J., Morenoff, J.D., \& Gannon-Rowley, T. (2002). Assessing "Neighborhood Effects": Social Processes and New Directions in Research. Annual Review of Sociology, 28(1), 443-478. https://doi.org/10.1146/annurev.soc.28.110601.141114

Sarazzin, T. (2010). Deutschland schafft sich ab: Wie wir unser Land aufs Spiel setzen. Munchen: DVA Verlag.

Save The Children. (2016). Children on the move. Retrieved from https://resourcecentre. savethechildren.net/keyword/children-move

Sawicki, K. (2016). Obcy w obcym kraju. Profilaktyka i resocjalizacja w środowiskach migranckich. Probacja, (2), 95-105.

Sawicki, K. (2017). Migranci w Europie. Uwarunkowania i metody integracji-przykład Holandii. Pogranicze. Studia Społeczne, XXX, 80-94. https://doi.org/10.15290/pss.2017.30.06

Strabac, Z., \& Listhaug. (2008). Anti-Muslim prejudice in Europe: A multilevel analysis of survey data from 30 countries. Social Science Research, 37(1), 268-286. https://doi. org/10.1016/j.ssresearch.2007.02.004

UN. (2000). Protocol To Prevent, Suppress and Punish Trafficking In Persons, Especially Women and Children, Supplementing The United Nations Convention Against Transnational Organized Crime.

Ungar, M. (2013). Resilience, Trauma, Context, and Culture. Trauma, Violence, \& Abuse, 14(3), 255-266. https://doi.org/10.1177/1524838013487805

UNICEF. (2018, December). Child migration. Retrieved from https://data.unicef.org/topic/ child-migration-and-displacement/migration/

UNODC. (2016). The definition of trafficking in persons and the mandate for the Global Report. Retrieved from United Nations Ofice on Drugs and Crime website: https://www.unodc. org/documents/data-and-analysis/glotip/Annex_II_-_Definition_and_mandate.pdf

Wacquant, L.J.D. (1996). The rise of advanced marginality: notes on its nature and implications. Acta Sociologica, (39), 121-139. https://doi.org/10.1177/000169939603900201

Wessels, W.K. (2014). The Refugee Experience: Involving Pre-migration, In Transit, and Post Migration Issues in Social Services. Retrieved from https://sophia.stkate.edu/msw_ papers/409

Wilson, W.J. (1987). The Truly Disadvantaged: The Inner City, the Underclass, and Public Policy. Chicago: University of Chicago Press.

Wyn, J., \& White, R. (1997). Rethinking Youth. Crows Nest: Allen\&Unwin. 